\title{
EPIDEMIOLOGY AND ANTIBIOTIC RESISTANCE PROFILE OF BACTERIAL UROPATHOGENS IN MALE PATIENTS: A 10-YEAR RETROSPECTIVE STUDY
}

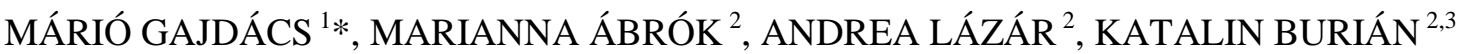 \\ ${ }^{I}$ Department of Pharmacodynamics and Biopharmacy, Faculty of Pharmacy, University of Szeged, Eötvös utca 6, 6720 \\ Szeged, Hungary \\ ${ }^{2}$ Institute of Clinical Microbiology, Faculty of Medicine, University of Szeged, Semmelweis utca 6, 6725 Szeged, Hungary \\ ${ }^{3}$ Department of Medical Microbiology and Immunobiology, Faculty of Medicine, University of Szeged, Dóm tér 10, 6720 \\ Szeged, Hungary
}

*corresponding author: mariopharma92@gmail.com

Manuscript received: August 2020

\begin{abstract}
The purpose of our present study was to establish the incidence of UTIs in adult male patients in the Southern region of Hungary over a long surveillance period (2008 - 2017). The antimicrobial susceptibility testing was performed using the disk diffusion method. Overall, $n=3750$ of these outpatient samples $(17.73 \%)$ and $n=5902$ of inpatient samples (30.54\%) originated from male patients. Members of the Enterobacteriaceae family were the most commonly isolated (outpatient: $64.4 \%$, inpatient: 55.57\%), with E. coli being the most common urinary pathogen in male patients (outpatient: $37.23 \%$, inpatient: 27.40\%), followed by Enterococcus spp. (outpatient: $22.72 \%$, inpatient: $23.43 \%$ ), and P. aeruginosa (outpatient: $7.15 \%$, inpatient: 9.2\%). Between 2010 and 2017, $\mathrm{n}=501$ (62.65 \pm 13.51 per year) extended-spectrum $\beta$-lactamase (ESBL) - positive isolates were recorded from outpatients and $n=737(105.28 \pm 31.99$ per year $)$ from inpatients $(p=0.032)$. Similarly to other bacterial infections, patients affected by drug-resistant urinary pathogens may encounter a poor clinical outcome and complications.
\end{abstract}

\section{Rezumat}

Scopul studiului prezentat a fost de a stabili incidența infecțiilor de tract urinar (UTI) la pacienții de sex masculin adulți din regiunea sudică a Ungariei pe o perioadă lungă de supraveghere $(2008$ - 2017). Testul de sensibilitate antimicrobiană a fost efectuat folosind metoda de difuzie a discului. În ansamblu, 3750 dintre aceste probe au provenit de la pacienți tratați ambulator (17,73\%) și 5902 de probe de la pacienți internați (30,54\%) de sex masculin. Membrii familiei Enterobacteriaceae au fost cei mai frecvent izolați patogeni (ambulatoriu: 64,4\%, internați: 55,57\%), E. coli fiind cel mai frecvent agent patogen la pacienții de sex masculin (ambulatoriu: 37,23\%, internați: 27,40\%), urmat de Enterococcus spp. (ambulatoriu: 22,72\%, internaţi: 23,43\%) şi P. aeruginosa (ambulatoriu: 7,15\%, internaţi: 9,2\%). Între 2010 şi 2017, 501 (62,65 $\pm 13,51$ pe an) izolate ESBL-pozitive au fost înregistrate de la pacienţi din ambulator şi $737(105,28 \pm 31,99$ pe an $)$ de la pacienți internați $(p=0,032)$. În mod similar cu alte infecții bacteriene, pacienții afectați de agenți patogeni rezistenți la medicamente pot avea rezultate clinice slabe și pot înregistra diferite complicații.

Keywords: urinary tract infections, UTIs, male patients, epidemiology, resistance

\section{Introduction}

Urinary tract infections (UTIs) are pathologies affecting a part of an individual's urinary system, including the bladder, urethra or the kidneys. UTIs are the second common type of infections in human medicine, representing around $10-30 \%$ of community-acquired and $25-50 \%$ of nosocomial infections worldwide $[21,32,33,37]$. They are considered as an important factor of morbidity and mortality and an important economic burden (the medical care of these patients, together with the loss of productivity associated with UTIs is estimated to cost around 5 billion US\$ per year) $[16,35]$. UTIs may also often correspond to serious complications, sequelae, recurrence and decreased quality of life (QoL) for the affected patients [15,
16, 21, 37]. Members of the Enterobacterales order, including uropathogenic strains of Escherichia coli (UPEC) and Klebsiella pneumoniae (UPKP) are some of the most important causes of uncomplicated and community-acquired urinary tract infections, in addition to Enterococcus spp., Staphylococcus saprophyticus (socalled "honeymoon cystitis") and Group B streptococci $[1,15,41]$. Nevertheless, causative agents of UTIs in nosocomial settings (especially in case of immunocompromised patients) may be much more diverse, including non-fermenting Gram-negative bacteria, $S$. aureus and fungal species, facilitating the increasing occurrence of unconventional urinary pathogens $[5$, $10,12,15,36]$. 
The incidence of UTIs differs considerably among different patient populations, including different genders, age groups and immune status: symptomatic UTI are far more common in women than in men. $30-50 \%$ of women experience uncomplicated cystitis at least once in their lifetime, while this ratio is around $0.5-5 \%$ for males [21, 23, 24]. In addition, the incidence of UTIs in males between 18 - 50 years of age is very low (5 - 8 per 10,000 patient/years), compared to the sharp increase in incidence over 50 years of age $[23,24,41]$. This may be explained by anatomical differences between the two sexes (longer urethral lengths, the lack of moisture in the periurethral environment, antibacterial substances originating from the prostatic fluids, less pronounced colonization of the urethra by potential urinary pathogens); however, symptomatic UTIs in males may be more severe and harder to treat [21-24, 41, 44]. Risk factors for males include lack of circumcision, anatomical abnormalities, having recent urinary procedures, an immunocompromised state and high-risk sexual practice [21-24, 41, 44]. Although several novel antibiotic agents have been approved for clinical use in recent 10 - 15 years, the therapy of UTIs (especially in outpatient settings) is becoming an important challenge for clinicians, due to the rapid development and spread of antimicrobial resistance (AMR) [19]. The growing prevalence of multidrug-resistant (MDR; i.e. exhibiting resistance to at least one agent, in at least three antibiotic categories) pathogens in UTIs limit therapeutic options considerably $[1,42]$. The increasingly common occurrence of extendedspectrum $\beta$-lactamase (ESBL) genes (encoded on plasmids) in the members of the Enterobacterales order is a cause of considerable worry both for clinicians and microbiologists worldwide; ESBLs confer resistance to classical penicillin-derivatives, such as broad-spectrum cephalosporins, which are all considered safe and effective therapeutic alternatives, forcing clinicians to utilize agents with a more pronounced toxicity profile (i.e. fluoroquinolones, such as ciprofloxacin or aminoglycosides, such as gentamicin) in the affected patients [14].

It is commonplace to treat patients with uncomplicated UTIs based on empirical antimicrobial therapy (without results of microbiological analyses or susceptibilitytesting); nonetheless, decisions on drug therapy may also be influenced by social and monetary aspects (such as the price of the drugs, drug availability and predicted adherence of the patients), drug allergies and tolerability of these antibiotics [13]. In outpatient cases, publications reporting on local epidemiological data are useful to guide therapeutic choices. However, there is a lack of data for the epidemiology and resistance trends for UTIs of specific patient groups, namely for males, children and transplant patients, therefore the choice of appropriate empiric antibiotic therapy may be hindered by the inability of assess local patterns of resistance $[23,43]$. Considering all these aspects, the aim of this paper was to report on the epidemiology and resistance trends of UTIs among adult males in a tertiary-care teaching hospital in the Southern region of Hungary over a long study period of 10 -years.

\section{Materials and Methods}

\section{Study design, data collection methods}

The present study was based on microbiological data collected for a 10-year surveillance period (2008.01.01 2017.12.31) at the Institute of Clinical Microbiology (University of Szeged, Hungary). The design of the study is retrospective. The Institute is the main diagnostic laboratory of the Albert Szent-Györgyi Health Centre, which is a primary- and tertiary-care teaching hospital in Szeged, Hungary. At the time of the study, the Centre had a capacity of 1,820-beds (1,465 acute and 355 chronic beds, respectively), with an annual patient turnover of over 400,000 patients in the region, according to the data of the Hungarian National Health Insurance Fund (NEAK), from general practitioner (GP) level care to specialized medical interventions [31]. Data for the study was collected by the study authors via the MedBakter laboratory system for urine samples originating from adult male patients, positive for bacterial pathogens. Samples with clinically-relevant colony counts (usually $10^{5}<$ colony forming units $(\mathrm{CFU}) / \mathrm{mL}$ ) and bacteria (determined and interpreted by considering international guidelines for diagnosing UTIs and information supplied on microbiological analysis request forms), that were positive for the nitrite and leukocyte-esterase tests were included in the data for this survey [36]. Only the first isolate per patient was included in the study; isolates presenting with different antibiotic-susceptibility patterns were considered as different individual isolates. Samples from female patients and from patients $<18$ years of age were excluded from data collection. In addition, the age of the male patients and inpatient/outpatient status were also collected.

\section{Identification of bacterial isolates}

The cultivation of relevant bacterial isolates was carried out using standard bacteriological protocols. $10 \mu \mathrm{L}$ of each un-centrifuged urine sample was cultured on various non-selective and selective-differentiating media (such as blood agar, eosine methylene blue agar and UriSelect chromogenic agar plates (Bio-Rad, Berkeley, CA, USA)) with a calibrated loop, according to the manufacturer's instructions; plates were incubated at $37^{\circ} \mathrm{C}$ for $24-48 \mathrm{~h}$, aerobically. If the relevant pathogens presented in significant colony count, the plates went on for further processing. During 2008 2012, standard biochemical assays and the VITEK 2 Compact ID/AST (bioMérieux, Marcy-l'Étoile, France) were used for bacterial identification; from 2013 onward, this matrix-assisted laser desorption/ionization time-of-flight mass spectrometry (MALDI-TOF MS; Bruker Daltonics, Bremen, Germany) was also introduced 
into routine ID practice. The methodology of sample preparation for MALDI-TOF MS measurements was described previously $[12,36]$. MS assays were performed by the Microflex MALDI Biotyper (Bruker Daltonics, Bremen, Germany); spectrum analysis and ID were carried out by the MALDI Biotyper RTC 3.1 software (Bruker Daltonics) and the MALDI Biotyper Library 3.1.

Antimicrobial Susceptibility Testing (AST)

The evaluation of the resistance trends was carried out regarding the most prevalent UTI pathogens isolated from male patients, namely members of the order of Enterobacterales, P. aeruginosa and Enterococcus spp. Antimicrobial susceptibility testing (AST) was performed by standard disk diffusion methodologies on Mueller-Hinton agar plates (Liofilchem, Abruzzo, Italy) described by the European Committee on Antimicrobial Susceptibility Testing (EUCAST), including. During AST, the susceptibility to the following antibiotics were tested (taking into consideration intrinsic resistance of isolates): ampicillin $(10 \mu \mathrm{g})$, amoxicillin/clavulanic acid $(20 / 10 \mu \mathrm{g})$, cefuroxime (30 $\mu \mathrm{g})$, ceftriaxone $(30 \mu \mathrm{g})$, ceftazidime $(30 \mu \mathrm{g})$, piperacillin/tazobactam $(30 / 6 \mu \mathrm{g})$, cefepime $(30 \mu \mathrm{g})$, imipenem $(10 \mu \mathrm{g})$, meropenem $(10 \mu \mathrm{g})$, ciprofloxacin $(5 \mu \mathrm{g})$, levofloxacin $(5 \mu \mathrm{g})$, gentamicin $(10 \mu \mathrm{g})$, amikacin $(30 \mu \mathrm{g})$, trimethoprim-sulfamethoxazole $(23.75 / 1.25$ $\mu \mathrm{g})$, vancomycin $(5 \mu \mathrm{g})$ and linezolid $(30 \mu \mathrm{g})$. The interpretation of the results was based on EUCAST Clinical Breakpoints 9.0.

Discrepant results were verified using the VITEK 2 Compact ID/AST (bioMérieux, Marcy-l'Étoile, France) automated system. The following bacterial strains were used as quality controls: E. coli ATCC 25922, K. pneumoniae ATCC 700603, E. faecalis ATCC 29212 and $S$. aureus ATCC 29213. If AST results were indicative of ESBL-production among Enterobacterales (according to EUCAST recommendations), phenotypic detection was performed using ESBL Detection Set (MAST Diagnostica GmbH, Reinfeld, Germany) from 2010 onward, with adherence to manufacturer's instructions [17].

Statistical Analysis

Descriptive statistical analysis, normality tests (ShapiroWilk) and non-parametric tests (Mann-Whitney U test) with the SPSS software version 22 (IBM SPSS Statistics for Windows 22.0, Armonk, NY, USA, IBM Corp.) were used. $\mathrm{p}$ values $<0.05$ were considered statistically significant.

\section{Results and Discussion}

The length of our surveillance study was 10-years, starting from 2008 and ending with 2017; in this period, the Institute had processed 21,150 positive urine samples from outpatient clinics and 19,325 positive urine samples from inpatient departments. Overall, $\mathrm{n}=3750$ of these outpatient samples $(17.73 \%)$ and $\mathrm{n}=5902$ of inpatient samples $(30.54 \%)$ originated from male patients who were 18 years or older at the time of sample submission. The sample distribution of the positive urine samples for males was the following: in outpatients $74.17 \%$ was midstream urine, while in inpatients $67.30 \%$ was catheter-specimen urine. Other samples types, such as first-stream urine, suprapubic bladder aspiration and urine obtained after a prostate massage were less common in both groups $(4.01 \%$ and $1.64 \%$ overall) (Figure 1).

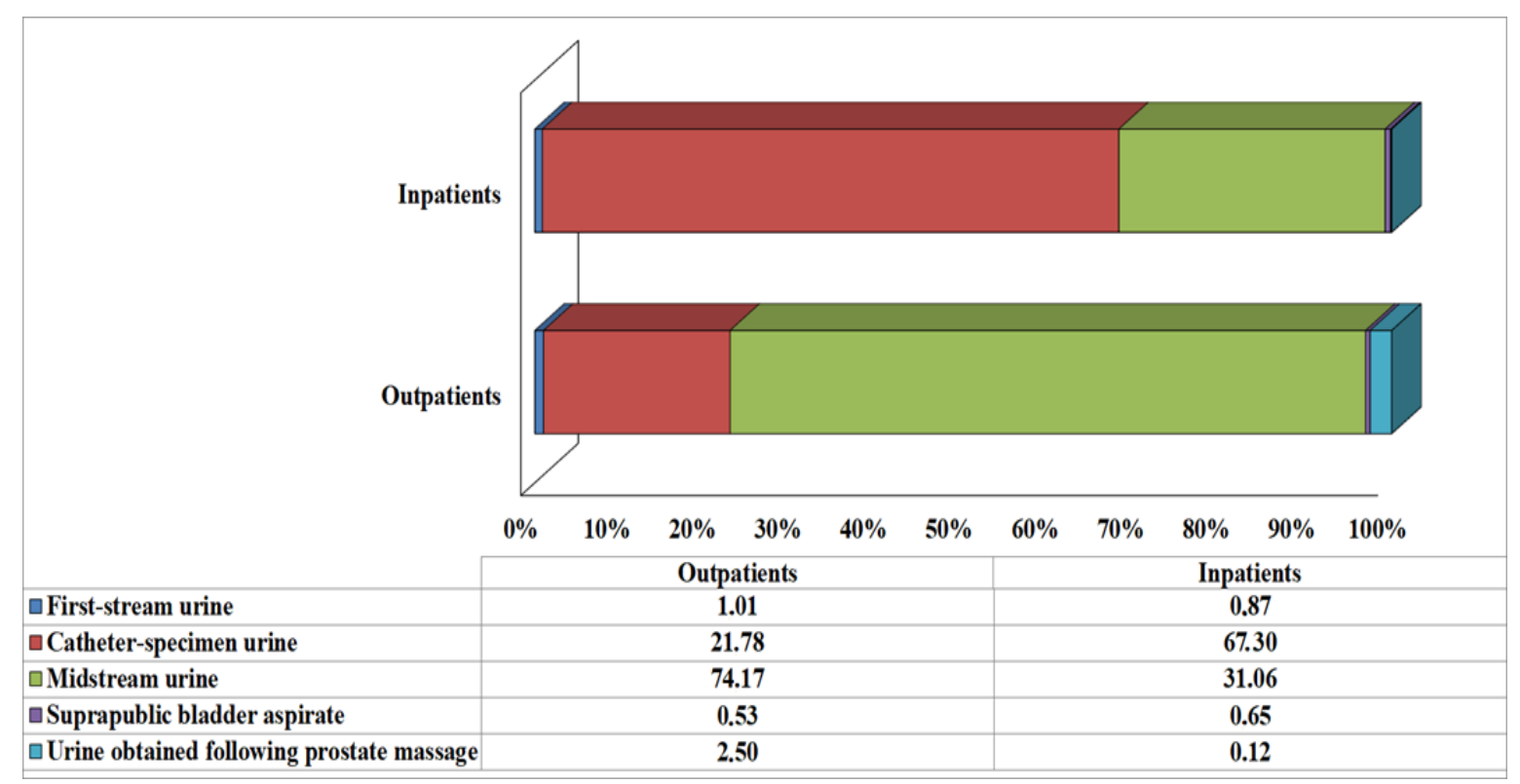

Figure 1.

Sample distribution from the outpatient and inpatient departments over the 10-year period 


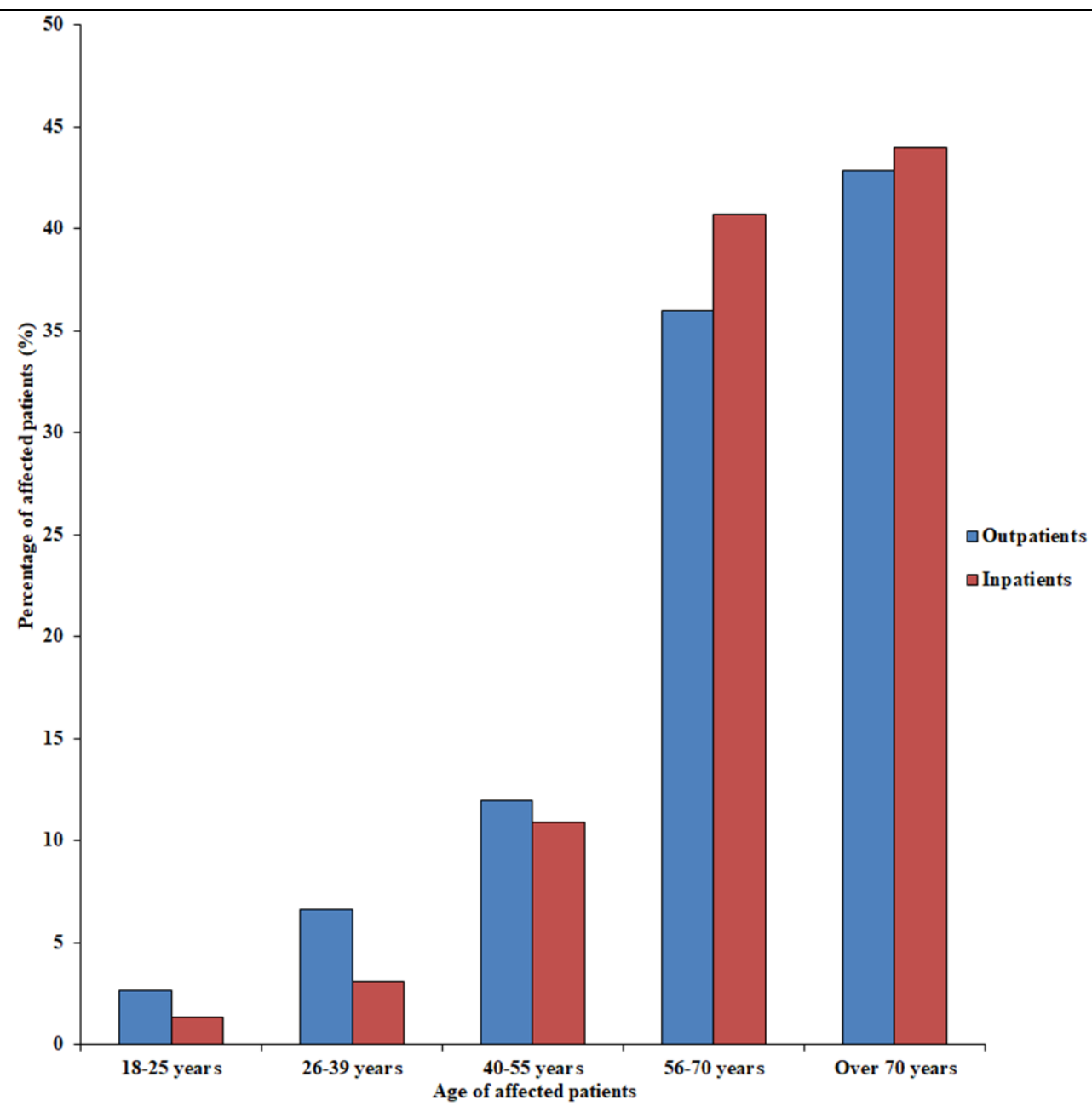

Figure 2.

Age distribution of the affected patients in the outpatient and inpatient groups

The median age of affected patients was 55 years (range: 18 - 97) in the outpatient group, while in the inpatient group, the median age was 58 years (range: 18 - 96). In both inpatient and outpatient groups, patient aged 56 years or older constituted the overwhelming majority of patients $(78.81 \%$ and $84.68 \%$, respectively); patients over 70 years presented in the highest numbers ( $42.84 \%$ and $43.98 \%$, respectively) (Figure 2).

The species distribution of outpatient and inpatient isolates did not present high variance, 36 and 37 different pathogens were identified on the species-level, respectively (Table I and Table II). $72.96 \%$ of isolates were Gram-negative, $26.0 \%$ were Gram-positive,
$0.67 \%$ were yeasts and $0.37 \%$ were atypical bacteria in the out-patient group (Table I). As a comparison, $66.88 \%$ of urinary pathogens were Gram-negative, 26.92\% were Gram-positive, $6.15 \%$ were yeasts and $0.05 \%$ were atypical bacteria (Table II) in the inpatient group. Species-wise, the members of the Enterobacterales family were the most commonly isolated (outpatient: $64.4 \%$, inpatient: $55.57 \%$ ), with $E$. coli being the most common urinary pathogen in male patients (outpatient: 37.23\%, inpatient: $27.40 \%$ ), followed by Enterococcus spp. (outpatient: $22.72 \%$, inpatient: $23.43 \%$ ), and $P$. aeruginosa (outpatient: $7.15 \%$, inpatient: $9.2 \%$ ) (Table I and Table II).

Table I

Species-composition of the urinary isolates from outpatient samples, 2008 - 2017

\begin{tabular}{|c|c|c|c|c|c|c|c|c|c|c|c|c|}
\hline & \multicolumn{10}{|c|}{ Study year } & & \\
\hline Isolated species & 2008 & 2009 & 2010 & 2011 & 2012 & 2013 & 2014 & 2015 & 2016 & 2017 & $\mathbf{N}$ & $\%$ \\
\hline Achromobacter xylosoxidans & & & & & & & & & 2 & & 2 & 0.05 \\
\hline Acinetobacter baumannii & 3 & 1 & & & 2 & & 5 & 4 & 2 & 5 & 22 & 0.59 \\
\hline A. lwoffi & 3 & & & 1 & 2 & 4 & 2 & & & 1 & 13 & 0.35 \\
\hline A. junii & & 1 & & & & & & & 1 & 1 & 3 & 0.08 \\
\hline Burholderia cepacia & & & 3 & & & 2 & & & & & 5 & 0.13 \\
\hline Candida albicans & & & 2 & & & & 5 & 8 & 2 & 2 & 19 & 0.51 \\
\hline
\end{tabular}


FARMACIA, 2021, Vol. 69, 3

\begin{tabular}{|c|c|c|c|c|c|c|c|c|c|c|c|c|}
\hline \multirow[b]{2}{*}{ Isolated species } & \multicolumn{10}{|c|}{ Study year } & \multirow[b]{2}{*}{$\mathbf{N}$} & \multirow[b]{2}{*}{$\%$} \\
\hline & 2008 & 2009 & 2010 & 2011 & 2012 & 2013 & 2014 & 2015 & 2016 & 2017 & & \\
\hline C. glabrata & & & & 1 & & & & & & 1 & 2 & 0.05 \\
\hline C. parapsilosis & & & & & & & & & 1 & & 1 & 0.03 \\
\hline C. tropicalis & & & & & & 2 & 1 & & & & 3 & 0.08 \\
\hline Citrobacter freundii & 1 & 3 & 2 & & 2 & 2 & & & & 1 & 11 & 0.29 \\
\hline C. koseri & 1 & & 1 & 2 & 2 & 5 & & 5 & 7 & 8 & 31 & 0.83 \\
\hline Enterobacter asburiae & & & & & & 3 & 1 & & 1 & 1 & 6 & 0.16 \\
\hline E. cloacae & 3 & 7 & 5 & 5 & 6 & 5 & 3 & 10 & 11 & 9 & 64 & 1.71 \\
\hline E. kobei & & & & & & 1 & 6 & 4 & & 2 & 13 & 0.35 \\
\hline Enterococcus faecalis & 85 & 62 & 60 & 61 & 72 & 68 & 83 & 111 & 100 & 131 & 833 & 22.21 \\
\hline E. faecium & & 2 & & 4 & 3 & 2 & & 2 & 1 & 5 & 19 & 0.51 \\
\hline Escherichia coli & 80 & 63 & 123 & 117 & 111 & 144 & 176 & 196 & 186 & 200 & 1396 & $\mathbf{3 7 . 2 3}$ \\
\hline Klebsiella aerogenes & 1 & 2 & 3 & 4 & 1 & 2 & & 3 & 3 & 8 & 27 & 0.72 \\
\hline K. oxytoca & 4 & & 4 & & 5 & 11 & 9 & 11 & 6 & 12 & 62 & 1.65 \\
\hline K. pneumoniae & 27 & & 74 & & 42 & 71 & 39 & 74 & 67 & 90 & 484 & 12.91 \\
\hline Mycoplasma hominis & & & & 2 & & & & & & & 2 & 0.05 \\
\hline Morganella morganii & & & 1 & 2 & 2 & 4 & 1 & 3 & 7 & 4 & 24 & 0.64 \\
\hline Proteus mirabilis & 5 & 4 & 14 & 18 & 18 & 25 & 32 & 38 & 40 & 55 & 249 & 6.64 \\
\hline P. vulgaris & 3 & 4 & 6 & 2 & 2 & 3 & 5 & 4 & 5 & & 34 & 0.91 \\
\hline Providencia rettgerii & & & & & & & & & 1 & & 1 & 0.03 \\
\hline P. stuartii & & & & & & & & & & 1 & 1 & $\mathbf{0 . 0 3}$ \\
\hline Pseudomonas aerugnosa & 28 & 25 & 21 & 37 & 25 & 32 & 23 & 24 & 25 & 28 & 268 & 7.15 \\
\hline Serratia marcescens & & 1 & & & & & 1 & 3 & 6 & 1 & 12 & 0.32 \\
\hline Staphylococcus aureus & & 1 & & 8 & 8 & 7 & 8 & 8 & 10 & 9 & 59 & 1.57 \\
\hline S. saprophyticus & & & & & 1 & & & & 3 & & 4 & 0.11 \\
\hline S. epidermidis & & 3 & 5 & 1 & & 4 & & & & & 13 & 0.35 \\
\hline S. hominis & 4 & 2 & & & & & & & & & 6 & 0.16 \\
\hline S. haemolyticus & & & & & & 1 & & & & & 1 & $\mathbf{0 . 0 3}$ \\
\hline Stenotrophomonas maltophilia & 1 & & & 1 & & 2 & & 2 & 1 & 1 & 8 & 0.21 \\
\hline Streptococcus agalactiae & 5 & 5 & 3 & 2 & 3 & 4 & 2 & 6 & 5 & 5 & 40 & 1.07 \\
\hline Ureaplasma urealyticum & 2 & & & 2 & & 4 & 1 & 1 & 2 & & 12 & 0.32 \\
\hline
\end{tabular}

Table II

Species-composition of the urinary isolates from inpatient samples, 2008 - 2017

\begin{tabular}{|c|c|c|c|c|c|c|c|c|c|c|c|c|}
\hline & \multicolumn{10}{|c|}{ Study year } & & \\
\hline $\begin{array}{l}\text { Isolated species } \\
\end{array}$ & 2008 & 2009 & 2010 & 2011 & 2012 & 2013 & 2014 & 2015 & 2016 & 2017 & $\mathbf{N}$ & $\%$ \\
\hline Achromobacter xylosoxidans & & & 1 & & & & & & & & 1 & 0.02 \\
\hline Acinetobacter baumannii & 2 & 3 & 7 & 3 & 14 & 11 & 8 & 9 & 6 & 5 & 68 & 1.15 \\
\hline A. lwoffi & & 1 & & & & & & 10 & 2 & & 13 & 0.22 \\
\hline A. junii & & & & & & & & 1 & & & 1 & 0.02 \\
\hline Burholderia cepacia & 8 & 1 & 2 & 4 & 2 & 1 & 2 & & & 1 & 21 & 0.36 \\
\hline Candida albicans & 10 & 15 & 18 & 8 & 11 & 22 & 33 & 30 & 33 & 60 & 240 & 4.07 \\
\hline C. glabrata & 3 & 4 & 2 & 4 & 2 & 2 & 8 & 20 & 5 & 11 & 61 & 1.03 \\
\hline C. parapsilosis & & 3 & 1 & & 3 & 1 & 2 & 5 & & 4 & 19 & 0.32 \\
\hline C. krusei & & & 1 & 2 & 2 & 4 & 2 & 2 & 2 & 4 & 19 & 0.32 \\
\hline C. tropicalis & 3 & & 6 & 1 & 3 & 1 & 2 & 4 & & 4 & 24 & 0.41 \\
\hline Citrobacter freundii & 2 & & 1 & 1 & & & & 2 & 2 & 2 & 10 & 0.17 \\
\hline C. koseri & & 2 & 2 & 1 & & 5 & & 6 & 2 & 5 & 23 & 0.39 \\
\hline Enterobacter asburiae & & & & & & 1 & & & & & 1 & 0.02 \\
\hline E. cloacae & 9 & 10 & 19 & 9 & 12 & 14 & 14 & 11 & 7 & 8 & 113 & 1.91 \\
\hline E. kobei & & & 1 & & & & & 4 & 2 & 4 & 11 & 0.19 \\
\hline Enterococcus faecalis & 108 & 92 & 95 & 105 & 120 & 142 & 152 & 138 & 161 & 158 & 1271 & 21.54 \\
\hline E. faecium & 5 & 14 & 7 & 7 & 7 & 13 & 13 & 7 & 21 & 18 & 112 & 1.90 \\
\hline Escherichia coli & 105 & 103 & 142 & 174 & 165 & 164 & 208 & 209 & 192 & 155 & 1617 & 27.40 \\
\hline Klebsiella aerogenes & 3 & 3 & 4 & 6 & 5 & 1 & 4 & 1 & 3 & 2 & 32 & 0.54 \\
\hline K. oxytoca & 6 & 4 & 6 & 9 & 6 & 9 & 14 & 9 & 15 & 15 & 93 & 1.58 \\
\hline K. pneumoniae & 42 & 43 & 73 & 68 & 87 & 72 & 110 & 99 & 117 & 79 & 790 & 13.39 \\
\hline Mycoplasma hominis & & & & 3 & & & & & & & 3 & 0.05 \\
\hline Morganella morganii & 3 & 2 & 1 & & & & 3 & 6 & 17 & 5 & 37 & 0.63 \\
\hline Proteus mirabilis & 16 & 20 & 30 & 54 & 44 & 45 & 72 & 79 & 58 & 52 & 470 & 7.96 \\
\hline
\end{tabular}


FARMACIA, 2021, Vol. 69, 3

\begin{tabular}{|c|c|c|c|c|c|c|c|c|c|c|c|c|}
\hline \multirow[b]{2}{*}{ Isolated species } & \multicolumn{10}{|c|}{ Study year } & \multirow[b]{2}{*}{$\mathbf{N}$} & \multirow[b]{2}{*}{$\%$} \\
\hline & 2008 & 2009 & 2010 & 2011 & 2012 & 2013 & 2014 & 2015 & 2016 & 2017 & & \\
\hline P. vulgaris & 3 & 6 & 6 & 10 & 7 & 4 & 11 & 4 & 7 & 5 & 63 & 1.07 \\
\hline Providencia rettgerii & & & & & & 1 & & 1 & & 4 & 6 & $\mathbf{0 . 1 0}$ \\
\hline P. stuartii & & & & & & & & 1 & 3 & 1 & 5 & $\mathbf{0 . 0 8}$ \\
\hline Pseudomonas aerugnosa & 45 & 65 & 47 & 58 & 76 & 45 & 55 & 46 & 52 & 54 & 543 & 9.20 \\
\hline Serratia marcescens & 1 & 1 & & 2 & 2 & 1 & 5 & 2 & 1 & 4 & 19 & 0.32 \\
\hline Staphylococcus aureus & 10 & 13 & 9 & 11 & 9 & 11 & 8 & 6 & 13 & 8 & 98 & 1.66 \\
\hline S. saprophyticus & 3 & & 1 & & 3 & 3 & 2 & & 2 & 4 & 18 & 0.30 \\
\hline S. epidermidis & 6 & 7 & & 1 & & 3 & 1 & & 2 & & 20 & 0.34 \\
\hline S. hominis & 9 & & 2 & 3 & 3 & & & & & & 17 & 0.29 \\
\hline S. haemolyticus & & & & & & 4 & & & 2 & & 6 & $\mathbf{0 . 1 0}$ \\
\hline S. hominis & 9 & & & & & & & & & & 9 & 0.15 \\
\hline Stenotrophomonas maltophilia & & 1 & 1 & 1 & & 1 & 4 & & & 2 & 10 & $\mathbf{0 . 1 7}$ \\
\hline Streptococcus agalactiae & 5 & 7 & 3 & 5 & 3 & 4 & 3 & 5 & 1 & 2 & 38 & 0.64 \\
\hline
\end{tabular}

Susceptibility results were collected for the isolates that were the most numerous in the adult male patients, namely members of the Enterobacteriaceae family, Enterococcus spp. and P. aeruginosa (Table III), in addition, the distribution of ESBL-producing isolates was also assessed over the 8-year period, where data was available (2010 - 2017; Figure 3). During our study, intrinsic non-susceptibility of relevant bacteria was considered during the assessment. The highest resistance rates were seen for fluoroquinolones in all three groups of uropathogens (Enterobacterales, enterococci and $P$. aeruginosa); additionally, high levels of resistance were also shown in regards to $3^{\text {rd }}$ generation cephalosporins (3GS) and trimethoprimsulfamethoxazole in Enterobacterales (e.g., E. coli and Klebsiella spp.). For $P$. aeruginosa, both imipenem and meropenem resistance rates were $>10 \%$ for outpatients and $>20 \%$ for inpatients. Pronounced differences were observed when comparing the resistance levels of outpatient and inpatient isolates, in the following cases: 3GCs, ciprofloxacin, levofloxacin, gentamicin and trimethoprim-sulfamethoxazole-resistance in Enterobacterales, ciprofloxacin and levofloxacin resistance in Enterococcus spp., and ciprofloxacin, levofloxacin and ceftazidime-resistance in $P$. aeruginosa (Table III). Between 2010 and 2017, $\mathrm{n}=501(62.65 \pm 13.51 \mathrm{per}$ year) ESBL-positive isolates were recorded from outpatients and $n=737(105.28 \pm 31.99$ per year $)$ from inpatients $(\mathrm{p}=0.032)$ (Figure 3$)$. No carbapenemresistant isolates in Enterobacterales or vancomycinand linezolid-resistant Enterococcus isolates were detected from these samples.

Table III

Ratio of resistant isolates among common urinary tract pathogens isolated from male patients over the 10-year

\begin{tabular}{|c|c|c|c|c|c|c|c|c|c|}
\hline \multirow[b]{2}{*}{ Tested antibiotics } & \multicolumn{3}{|c|}{ Enterobacteriaceae } & \multicolumn{3}{|c|}{ Enterococcus spp. } & \multicolumn{3}{|c|}{\begin{tabular}{|l|} 
P. aeruginosa \\
\end{tabular}} \\
\hline & \begin{tabular}{|c|}
$\begin{array}{c}\text { Outpatients } \\
(\%)\end{array}$ \\
\end{tabular} & \begin{tabular}{|c|} 
Inpatients \\
$(\%)$
\end{tabular} & Statistics* & $\begin{array}{c}\text { Outpatients } \\
(\%)\end{array}$ & \begin{tabular}{|c|} 
Inpatients \\
$(\%)$
\end{tabular} & Statistics* & $\begin{array}{c}\text { Outpatients } \\
(\%)\end{array}$ & \begin{tabular}{|c|} 
Inpatients \\
$(\%)$
\end{tabular} & Statistics* \\
\hline Ampicillin & 39.85 & 51.11 & n.s. & 0.17 & 0.21 & n.s. & \multicolumn{3}{|c|}{-} \\
\hline $\begin{array}{l}\text { Amoxicillin/ } \\
\text { clavulanic acid }\end{array}$ & 18.16 & 20.05 & n.s. & 0.17 & 0.21 & n.s. & \multicolumn{3}{|c|}{-} \\
\hline Cefuroxime & 25.64 & 32.18 & $\mathrm{p}=0.043$ & \multicolumn{3}{|c|}{-} & \multicolumn{3}{|c|}{ - } \\
\hline Ceftriaxone & 24.91 & 31.97 & $\mathrm{p}=0.041$ & \multicolumn{3}{|c|}{-} & \multicolumn{3}{|c|}{-} \\
\hline Ceftazidime & 24.86 & 31.97 & $\mathrm{p}=0.04$ & \multicolumn{3}{|c|}{-} & 11.13 & 18.81 & $\mathrm{p}=0.041$ \\
\hline $\begin{array}{l}\text { Piperacillin/ } \\
\text { tazobactam }\end{array}$ & 24.86 & 31.97 & $\mathrm{p}=0.04$ & 0.17 & 0.21 & n.s. & \multicolumn{3}{|c|}{ - } \\
\hline Cefepime & 16.31 & 19.10 & n.s. & \multicolumn{3}{|c|}{-} & 13.56 & 20.01 & n.s. \\
\hline Imipenem & 0.0 & 0.0 & n.s. & 0.03 & 0.07 & n.s. & 13.26 & 24.91 & \\
\hline Meropenem & 0.0 & 0.0 & n.s. & \multicolumn{3}{|c|}{-} & 12.50 & 21.07 & \\
\hline Ciprofloxacin & 22.17 & 34.57 & $\mathrm{p}=0.029$ & 34.15 & 19.28 & $\mathrm{p}=0.019$ & 33.00 & 43.78 & $\mathrm{p}=0.039$ \\
\hline Levofloxacin & 20.10 & 31.96 & $\mathrm{p}=0.31$ & 32.05 & 17.17 & $\mathrm{p}=0.022$ & 33.00 & 43.78 & $\mathrm{p}=0.039$ \\
\hline Gentamicin & 10.17 & 19.35 & $\mathrm{p}=0.02$ & \multicolumn{3}{|c|}{-} & \multicolumn{3}{|c|}{-} \\
\hline Amikacin & 5.52 & 7.23 & n.s. & \multicolumn{3}{|c|}{-} & 15.56 & 18.21 & n.s. \\
\hline $\begin{array}{l}\text { Trimethoprim- } \\
\text { sulfamethoxazole }\end{array}$ & 25.45 & 36.68 & $\mathrm{p}=0.03$ & \multicolumn{3}{|c|}{-} & \multicolumn{3}{|c|}{-} \\
\hline Vancomycin & \multicolumn{3}{|c|}{-} & 0.0 & 0.0 & n.s. & \multicolumn{3}{|c|}{-} \\
\hline Linezolid & \multicolumn{3}{|c|}{-} & 0.0 & 0.0 & n.s. & \multicolumn{3}{|c|}{ - } \\
\hline
\end{tabular}

*Comparison of resistance levels among isolates originating from outpatients and inpatients; n.s.: not significant 


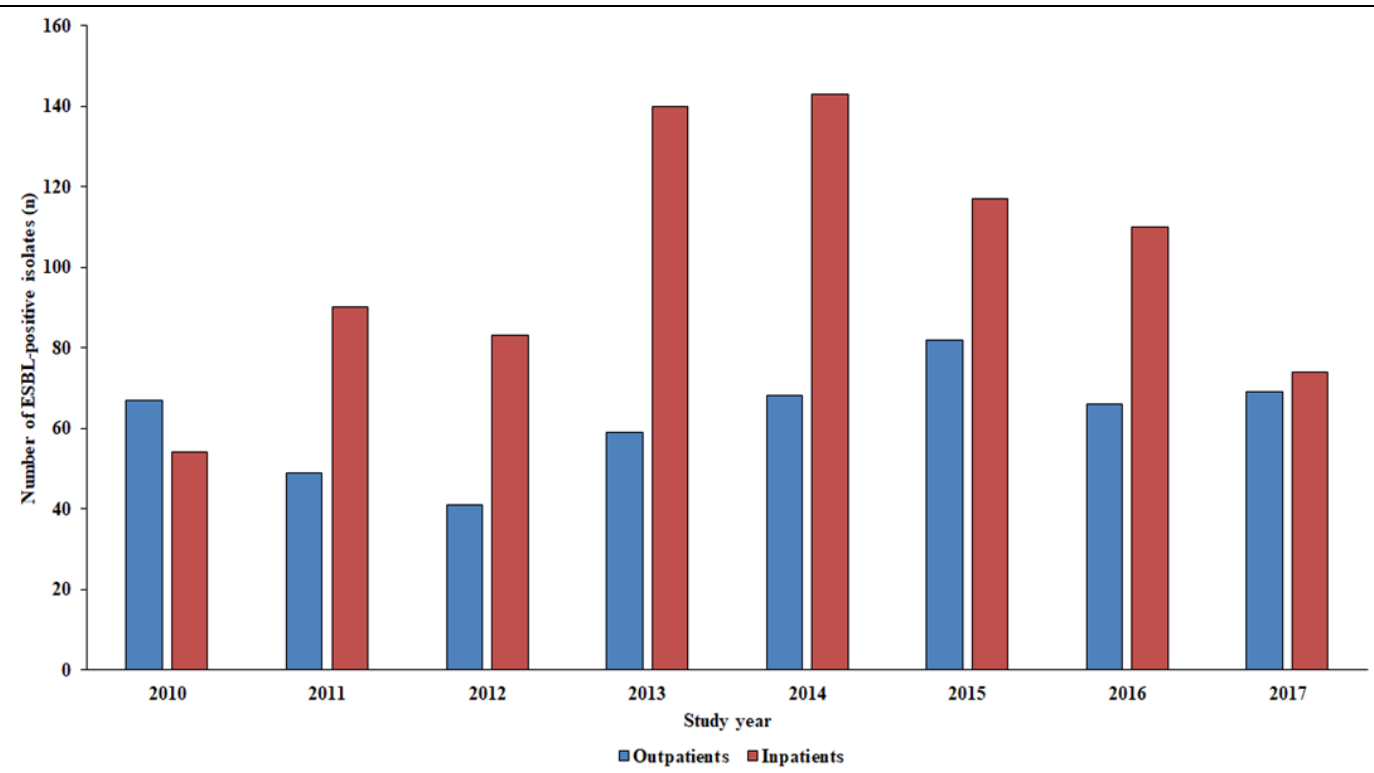

Figure 3.

Distribution of ESBL-producing isolates

The principal aim of our research was to provide reliable epidemiological information regarding UTIs in adult male patients in the southern region of Hungary over a long surveillance period, focusing on bacterial composition and resistance trends in the most numerous isolates. The epidemiology and resistance of urinary pathogens from female patients in the geographic region has been described previously: in these reports, similar resistance trends were observed for the most common urinary pathogens $[12,17,25,34,36]$.

Nevertheless, the ratio of ESBL-positivity was higher in isolates from male patients than in females. The data presented here may contribute to the creation of a national/transnational surveillance program for male UTIs, as previously, international surveillance reports (e.g., SENTRY [22, 26], SMART [29], ESGNI-003 [8], PEP-study [22, 26], MYSTIC [45]) mainly focus on data on nosocomial UTIs, affecting both genders. In comparison with the already-published data in the available literature, our has provided similar conclusions, both regarding the species-composition of the relevant pathogens (E. coli, K. pneumoniae and Enterococcus, which are constituents of the normal intestinal microbiota and $P$. aeruginosa, a common colonizer in nosocomial environments) and the prevalence of UTIs in different age groups (> $40 \%$ of affected patients were over 70 years of age) [24, 26]. In male patients, the critical assessment of the symptoms is important for differentialdiagnostics, as urinary frequency, urgency, dysuria and pyuria may also indicate bacterial prostatitis. If the symptoms of the patients persist for a long period of time, or they are coupled with malaise, myalgia, pain from the perineal region, with fever, chills and urinary retention, there is a high-risk that the prostate is affected (e.g., benign prostate hyperplasia) [19, 24].
The development of UTIs in consequence of urinary pathogens is dependent on the presence of various virulence-determinants, that associated with host colonization, tissue invasion and damage, the evasion of mucosal immunity and elimination of the host's humoral immune response $[4,6,15,32,33,38]$. The abovementioned virulence determinants include proteinbased agents, such as adhesins, toxins, capsuleproduction, biofilm (especially in catheter-associated infections), siderophore (iron-uptake) systems, lipopolysaccharide (LPS), and $\mathrm{O}$ - and $\mathrm{H}$-antigens (in select Gram-negative bacteria) $[4,6,15,32,33,38]$. Most of these are associated with UPEC and UPKP; however, the majority may also be found in $P$. aerugonisa and Enterococcus spp.

Similarly to other bacterial infections, patients affected by drug-resistant urinary pathogens may observe a poor clinical outcome and complications [3, 27]. Nevertheless, with the extensive clinical use of antibiotics, the development of bacterial resistance simultaneously and inevitably occurs; thus the prudent use of these drugs in all settings is of critical relevance [3, 18, 27]. The most common pathogens isolated in this study are all members of the so-called "ESKAPE" pathogens, designated by the World Health Organisation as the most important drug resistant bacteria, warranting attention from pharmaceutical companies and national infection control experts [7, 19, 40]. Trimethoprimsulfamethoxazole, fosfomycin and nitrofurantoin (in case of $E$. coli) are regarded as first-choice antibiotics in uncomplicated UTIs; while if there are allergies or intolerance to these agents, several $\beta$-lactam antibiotics and fluoroquinolones also offer viable alternatives, although the relevance of fluoroquinolones has been called into question many times, due to the mounting evidence of their serious, debilitating adverse effects 
$[39,43]$. However, it must be noted that if an isolate shows resistance to the abovementioned drugs, there are essentially no other orally-available options left for treat UTIs in the outpatient settings; this is especially true in case of $P$. aeruginosa and enterococci, as the list of clinically-useful drugs is already limited in wildtype strains [4, 14, 21]. There has been renewed interest in the acidification of urine and the use of urinary disinfectants (e.g., methenamine) to spare antibiotics $[2,20]$. For Gram-negative bacteria, the presence of $\beta$ lactamases is one of the most significant mechanisms of resistance, although alterations in porin channels and the cell wall may also lead to resistance for $\beta$ lactam antibiotics [2, 3, 27]. In the Enterobacterales order, ESBL-production (sometimes together with chromosomally-encoded or plasmid-mediated AmpCenzyme production) is an important therapeutic concern; since the $21^{\text {st }}$ century, the $b l a_{\text {CTX-M-type enzymes have }}$ become the most prevalent worldwide $[9,11,14,28$, 30]. In addition, ESBL-positivity is also alarming from the standpoint of infection control, as these genes are found on large plasmids or integrons, which may include other resistance-determinants, leading to the rapid development of MDR in these isolates [11, 28, 30].

Although our study highlight the importance of this research field and provides valuable data, several limitations of the research methods should be considered: the study design was retrospective, and the medical records of the individual patients could not be accessed; subsequently, the correlation between bacterial isolation and other laboratory parameters, signs and symptoms, and the immune status of the patients could not be assessed. Selection bias is also present for this study (similarly to other epidemiological studies from tertiarycare hospitals), because our data presumably corresponds to patients with more severe conditions or underlying illnesses. In addition, during laboratory analyses, our study did not include the genotypic characterization of the causative isolates, such as determination of the presence of resistance genes or virulence factors.

\section{Conclusions}

This study presents the epidemiological trends and resistance levels of the main urinary pathogens associated with urinary tract infections (UTIs) in adult males. The study was carried out in the Southern region of Hungary over a long surveillance period (10 years). In the present study, Gram-negative strains were most prevalent in the UTIs of male patients, unsurprisingly, E. coli was the most common uropathogen detected. The study also revealed that all the major strains showed high levels of resistance against fluoroquinolones and in the case of Enterobacteriaceae, also for broad-spectrum cephalosporins, due to the production of ESBL-enzymes. The renaissance of old urinary antibiotics, e.g., nitrofurantoin and fosfomycin is warranted. To ensure safe and effective antimicrobial therapy to treat UTIs (empirically) in male patients, the continuous surveillance of causative agents and their resistance rates in these infections is definitely warranted.

\section{Acknowledgement}

M.G. was supported by the János Bolyai Research Scholarship (BO/00144/20/5) of the Hungarian Academy of Sciences and the New National Excellence Programme (ÚNKP) of the Hungarian Ministry for Innovation and Technology (ÚNKP-20-5-SZTE-330).

\section{Conflict of interest}

The authors declare no conflict of interest.

\section{References}

1. Abbo LM, Hooton TM, Antimicrobial stewardship and urinary tract infections. Antibiotics, 2014; 3(2): 174-192.

2. Al-Zarouni M, Senok A, Al-Zarooni, N, Al-Nassay F, Panigrahi D, Extended-spectrum beta-lactamaseproducing Enterobacteriaceae: In vitro susceptibility to fosfomycin, nitrofurantoin and tigecycline. Med Princ Pract., 2012; 21(1): 543-547.

3. Bader MS, Loeb M, Brooks AA, An update on the management of urinary tract infections in the era of antimicrobial resistance. Postgrad Med., 2017; 129(2): 242-258.

4. Behzadi P, Behzadi E, Yazdanbod H, Aghapour R, Akbari Cheshmeh M, Salehian Omran D, A survey on urinary tract infections associated with the three most common uropathogenic bacteria. Maedica (Bucharest), 2010; 5(1): 111-115.

5. Behzadi P, Behzadi E, Ranjbar, R, Urinary tract infections and Candida albicans. Cent European J Urol., 2015; 68(1): 96-101.

6. Behzadi P, Classical chaperone-usher (CU) adhesive fimbriome: uropathogenic Escherichia coli (UPEC) and urinary tract infections (UTIs). Folia Microbiol., 2020; 65: 45-65.

7. Boucher HW, Talbot GH, Bradley JS, Edwards JE, Gilbert D, Rice LB, Scheld M, Spellberg B, Bartlett J, Bad Bugs, No Drugs: No ESKAPE! An Update from the Infectious Diseases Society of America. Clin Infect Dis., 2009; 48(1): 1-12.

8. Bouza E, San Juan R, Muñoz P, Voss A, Kluytmans J; Co-operative Group of the European Study Group on Nosocomial Infections, A European perspective on nosocomial urinary tract infections II. Report on incidence, clinical characteristics and outcome (ESGNI-004 study). European Study Group on Nosocomial Infection. Clin Microbiol Infect., 2001; 7(10): 532-542.

9. Cai T, Palagin I, Brunelli R, Cipelli R, Pellini E, Truzzi JC, Van Bruwaene S, Office-based approach to urinary tract infections in 50000 patients: results from the REWIND study. Int J Antimicrob Agents, 2020; 56: e105966: 1-6.

10. Calzi A, Grignolo S, Caviglia I, Calevo MG, Losurdo G, Piaggio G, Bandettini R, Castagnola E, 
FARMACIA, 2021, Vol. 69, 3

Resistance to oral antibiotics in 4569 Gramnegative rods isolated from urinary tract infection in children. Eur J Pediatr., 2016; 175(9): 12191225.

11. Cantón R, González-Alba JM, Galán JC, CTX-M enzymes: Origin and diffusion. Front Microbiol., 2012; 3(1): e110: 1-19.

12. Chen CY, Chen YH, Lu PL, Lin WR, Chen TC, Lin CY, Proteus mirabilis urinary tract infection and bacteremia: Risk factors, clinical presentation, and outcomes. J Microbiol Immunol Infect., 2012; 45: 228-236.

13. Denes E, Prouzergue J, Ducroix-Roubertou S, Aupetit C, Weinbreck P, Antibiotic prescription by general practitioners for urinary tract infections in outpatients. Eur J Clin Microbiol Infect Dis., 2012; 31(11): 3079-3083.

14. Dhillon, RHP, Clark J, ESBLs: A clear and present danger? Crit Care Res Pract., 2012; 2012: 625170: $1-11$.

15. Flores-Mireles AL, Walker JN, Caparon M, Hultgren SJ, Urinary tract infections: Epidemiology, mechanisms of infection and treatment options. Nat Rev Microbiol., 2015; 13(5): 269-284.

16. Foxman B, Epidemiology of urinary tract infections: Incidence, morbidity, and economic costs. Dis Mon., 2003; 49(2): 53-70.

17. Gajdács M, Ábrók M, Lázár A, Burián $\mathrm{K}$, Comparative Epidemiology and Resistance Trends of Common Urinary Pathogens in a Tertiary-Care Hospital: A 10-Year Surveillance Study. Medicina, 2019; 55(7): e356: 1-15.

18. Gajdács M, Paulik E, Szabó A, Knowledge, Attitude and Practice of Community Pharmacists Regarding Antibiotic Use and Infectious Diseases: A Cross-Sectional Survey in Hungary (KAPPhAHU). Antibiotics, 2020; 9(2): e41: 1-17.

19. 22. Gill BC, Shoskes DA, Bacterial prostatitis. Curr Opin Infect Dis., 2016; 29(1): 86-91.

20. Giske CG, Contemporary resistance trends and mechanisms for the old antibiotics colistin, temocillin, fosfomycin, mecillinam and nitrofurantoin. Clin Microbiol Infect., 2015; 21(10): 899-905.

21. Gupta K, Hooton TM, Naber KG, Wullt B, Colgan R, Miller LG, Moran GJ, Nicolle LE, Raz R, Schaeffer AJ, Soper DE; Infectious Diseases Society of America; European Society for Microbiology and Infectious Diseases, International clinical practice guidelines for the treatment of acute uncomplicated cystitis and pyelonephritis in women: A 2010 update by the Infectious diseases society of America and the European society for microbiology and infectious diseases. Clin Infect Dis., 2011; 52(5): e103-e120.

22. Jones RN, Kugler KC, Pfaller MA, Winokur PL. Characteristics of pathogens causing urinary tract infections in hospitals in North America: results from the SENTRY antimicrobial surveillance program, 1997. Diagn Microbiol Infect Dis., 1999; 35(1): 55-63.

23. Krieger JN, Ross SO, Simonsen JM. Urinary tract infections in healthy university men. J Urol., 1993; 149(5): 1046-1048.
24. Lipsky BA, Ireton RC, Fihn SD, Hackett R, Berger $\mathrm{RE}$, Diagnosis of bacteriuria in men: specimen collection and culture interpretation. J Infect Dis., 1987; 155(5): 847-854.

25. Marsh K, Mundy L, Holter JJ, Johnson JR. Analysis of urine-specific antibiograms from veterans to guide empiric therapy for suspected urinary tract infection. Diagn Microbiol Infect Dis., 2019; 95: e114874: 1-14.

26. Mathia D, Jones RN, Pfaller MA, Epidemiology and frequency of resistance among pathogens causing urinary tract infections in 1,510 hospitalized patients: a report from the SENTRY Antimicrobial Surveillance Program (North America). Diagn Microbiol Infect Dis., 2001; 40(2): 129-136.

27. Mazzariol A, Bazaj A, Cornaglia G, Multi-drugresistant Gram-negative bacteria causing urinary tract infections: A review. J Chemother., 2017; 29(1): 2-9.

28. Meier S, Weber R, Zbinden R, Ruef C, Hasse B. Extended-spectrum $\beta$-lactamase-producing Gramnegative pathogens in community-acquired urinary tract infections: An increasing challenge for antimicrobial therapy. Infection, 2011; 39(1): 333340.

29. Morrissey I, Hackel M, Badal R, Bouchillon S, Hawser S, Biedenbach D, A review of ten years of the study for monitoring antimicrobial resistance trends (SMART) from 2002 to 2011. Pharmaceuticals, 2013; 6(11): 1335-1346.

30. Moy S, Sharma R, Treatment Outcomes in Infections Caused by "SPICE" (Serratia, Pseudomonas, Indole-positive Proteus, Citrobacter, and Enterobacter) Organisms: Carbapenem versus Noncarbapenem Regimens. Clin Ther., 2017; 39(1): 170-176.

31. National Health Insurance Fund of Hungary. Hospital Bed Count and Patient Turnover Report 2017; National Health Insurance Fund of Hungary: Budapest, Hungary, 2017, www.neak.gov.hu.

32. Petca RC, Popescu RI, Mares C, Petca A, Mehedintu C, Sandu I, Maru N, Antibiotic resistance profile of common uropathogens implicated in urinary tract infections in Romania. Farmacia, 2019; 67(6): 994-1004.

33. Petca RC, Mares C, Popescu R, Petca A, Diaconescu D, Braticevici B, Jinga V, Antibiotic resistance profile of uropathogens strains implicated in the etiology of the urinary tract infections. Eur Urol Suppl., 2019; 18(2): e2397.

34. Pezzlo M, Laboratory Diagnosis of Urinary Tract Infections: Guidelines, Challenges, and Innovations. Clin Microbiol Newslett., 2014; 36(12): 87-93.

35. Simmering JE, Tang F, Cavanaugh JE, Polgreen LA, Polgreen PM, The Increase in Hospitalizations for Urinary Tract Infections and the Associated Costs in the United States, 1998-2011. Open Forum Infect Dis., 2017; 4: ofw281: 1-7.

36. Surgers L, Boyd A, Girard PM, Arlet G, Decré D. Biofilm formation by ESBL-producing strains of Escherichia coli and Klebsiella pneumonia. Int $J$ Med Microbiol., 2019; 309: 13-18. 
FARMACIA, 2021, Vol. 69, 3

37. Tandogdu Z, Wagenlehner FME. Global epidemiology of urinary tract infections. Curr Opin Infect Dis., 2016; 29(1): 73-79.

38. Terlizzi ME, Gribaudo G, Maffei ME, Uropathogenic Escherichia coli (UPEC) Infections: Virulence Factors, Bladder Responses, Antibiotic, and Non-antibiotic Antimicrobial Strategies. Front Microbiol., 2017; 8: 1566: 1-23.

39. Trautner BW, Fluoroquinolones for urinary tract infection and within-household spread of resistant Enterobacteriaceae: The smoking gun. Clin Microbiol Infect., 2018; 24(1): 929-930.

40. Voicu M, Cristescu C, Zbârcea CE, Voicu A, Buda V, Suciu L, Suciu M, Proks M, Bild V, Comparative study of antimicrobials use and the antibiotic resistance of Gram-negative strains. Farmacia, 2017; 65(2): 225-229.

41. Wagenlehner F, Tandogdu Z, Bartoletti R, Cai T, Cek M, Kulchavenya E, Köves B, Naber K, Perepanova T, Tenke P, Wullt B, Bogenhard F, Johansen TE, The global prevalence of infections in urology study: A long-term, worldwide surveillance study on urological infections. Pathogens, 2016; 5(1): 10: 1-8.

42. Walker E, Lyman A, Gupta K, Mahoney MV, Snyder GM, Hirsch EB, Clinical Management of an Increasing Threat: Outpatient Urinary Tract Infections Due to Multidrug-Resistant Uropathogens. Clin Infect Dis., 2016; 63(1): 960-965.

43. Wiedemann B, Heisig A, Heisig P, Uncomplicated urinary tract infections and antibiotic resistanceepidemiological and mechanistic aspects. Antibiotics, 2014; 3(3): 341-352.

44. Wilson ML, Gaido L, Laboratory diagnosis of urinary tract infections in adult patients. Clin Infect Dis., 2004; 38(8): 1150-1158.

45. Zarakolu P, Hasçelik G, Unal S, Antimicrobial susceptibility pattern of nosocomial gram-negative pathogens: Results from MYSTIC study in Hacettepe University Adult Hospital (2000-2004). Mikrobiyol Bul., 2006; 40(1): 147-154.

46. www.eucast.org. 